

\title{
The Shifting Structure of China's Trade and Production
}

\author{
Li Cui and Murtaza Syed
}





\title{
IMF Working Paper
}

Asia and Pacific Department

The Shifting Structure of China's Trade and Production

\author{
Prepared by Li Cui and Murtaza Syed ${ }^{1}$
}

Authorized for distribution by Jahangir Aziz

September 2007

\begin{abstract}
This Working Paper should not be reported as representing the views of the IMF.

The views expressed in this Working Paper are those of the author(s) and do not necessarily represent those of the IMF or IMF policy. Working Papers describe research in progress by the author(s) and are published to elicit comments and to further debate.

This paper uses disaggregated trade data to assess how the expansion of China's production capacity and its changing production structure may be affecting its trade linkages with other countries. It finds that China is moving away from traditional assembly operations in its processing activities and its exports have started to rely more on domestically sourced components. In turn, China's imports and exports have begun to delink, with increased domestic sourcing contributing to the recent increase in its trade balance. In addition, as China moves up the value chain, both its imports and exports have become more sophisticated than in the past. As a result of these shifts, China may be becoming more exposed to fluctuations in the strength of the global economy, and changes in its exchange rate could have a bigger impact on the trade balance and the domestic economy than commonly believed.

JEL Classification Numbers: F1, F2, F4

Keywords: Value added, processing trade Authors’ E-Mail Addresses: 1cui@imf.org, msyed@imf.org

\footnotetext{
${ }^{1}$ The authors would like to thank, without implicating, Jahangir Aziz for his guidance and encouragement for exploring this topic. We thank Steve Dunaway, Lamin Leigh, Xiangming Li, and the participants of the IMF Research Conference on Global Implication of China's Trade, Investment, and Growth for their comments, and K.C. Fung for his suggestions and comments. We thank Mehmet Ziya Gorpe for his assistance with data analysis and Debra Loucks for preparing the document. The views expressed in this paper do not necessarily reflect those of the IMF or its China team.
} 


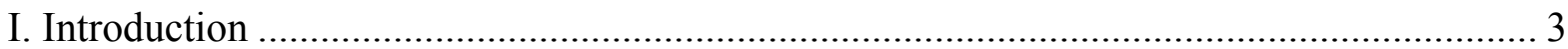

II. Recent Developments in China's External Trade .................................................. 5

III. Evaluating Trade Equations using Sectoral Data...................................................... 9

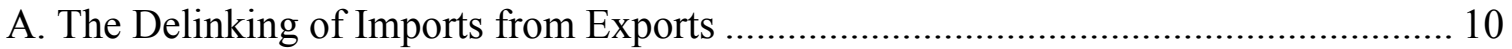

B. Product Sophistication and Trade Flows.................................................................. 14

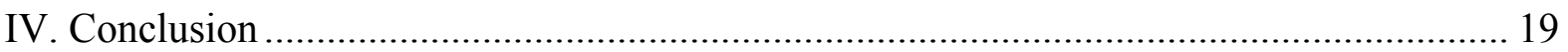

Tables

1. Testing Delinking of Imports and Exports: Full Sample, Alternative Specifications ...... 21

2. Testing Delinking of Imports and Exports: Sub-Sample Analysis ................................ 22

3. Robustness Checks: Sub-Sample Analysis using IV Estimation.................................. 23

4. Export Elasticities and Product Sophistication Level ................................................ 24

5. Import Elasticities and Product Sophistication Level ................................................ 25

6. Export-GDP Ratio and Product Sophistication Level ............................................. 26

7. Import-GDP Ratio and Product Sophistication Level ................................................ 27

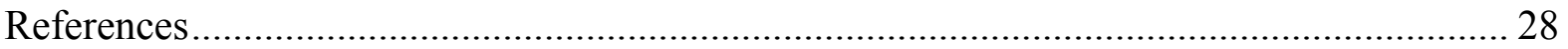




\section{INTRODUCTION}

The rapid expansion of China's trade surplus has been a key development in the global economy in recent times. The rise has also been vigorously debated as it is unclear what caused it. Some view the burgeoning trade surplus as a clear sign of unfair price competitiveness of Chinese exports due to an undervalued renminbi, while others have argued that it reflects changes in China's economic structure and associated shifts in its role within regional and global production chains. Rather than being one more paper on the equilibrium level of China's exchange rate and trying to measure what impact this may have had on the trade balance, this paper focuses on the latter aspect and tries to shed some light on the debate by looking into the shifts that have taken place in China's trade structure. ${ }^{2}$

The results are telling. There is a caricature about China's trade structure: using its abundant and cheap labor, China's vast coastal factories assemble and process imported inputs from the West and other parts of Asia into final goods to be sold abroad (often referred to as "processing trade" - a category coined by China's customs officials for tax purposes). According to this conventional "world assembler" view, as long as China retains its comparative advantage in cheap labor, movements in external demand and the exchange rate should have a very limited impact on its trade balance, as any change on the export side will be offset by a similar change on the import side. Indeed, relative price changes have typically been found to have relatively small effects on China's exports and trade balance in formal econometric analyses, which have been attributed to its role as a processing center (Shu and Yip (2006)).

Our analysis suggests that this caricature may have become less accurate over time. The structure of China's external trade in the last few years looks very different from that ten years ago, and while this caricature may have loosely fitted the Chinese economy in the early stages of reform when a lack of technological know-how meant that it had to rely on imported intermediate products and capital goods for production and exports, it increasingly appears not to be the case. Domestic production capacity has increased substantially in recent years, which has enabled increased domestic sourcing of exports and weakened the traditional tight link between exports and imports. Macroeconomic shocks may therefore have more potent effects on China's trade balance and domestic economy, because a slowdown in exports may not be offset by a commensurate decline in imports.

In addition, the greater sensitivity of trade balance to changes in global demand and relative prices may go beyond the shift in China's traditional role as a processing center and reflect changes in China's trade bundle. While consumption goods used to dominate China's exports, their share has declined sharply over the last decade, as exports of capital equipment

\footnotetext{
${ }^{2}$ See Dunaway, Leigh, and Li (2006), Coudert and Couharde (2005), and Goldstein (2004) for issues related to the estimation of China's equilibrium exchange rate.
} 
and intermediate products have increased significantly, accounting for more than 40 percent of China's total exports. Such a shift reflects the rising capacity of the country to produce more sophisticated products and could imply a change in demand and price elasticities for aggregate trade, if different products react differently to macroeconomic shocks. Indeed, we find that exports of sophisticated products tend to be more sensitive to aggregate demand and price changes, pointing to another channel by which China's exports and trade balance may have become more responsive to price and demand changes than estimated from historical averages.

A number of previous papers have examined shifts in China's trade structure. Lemoine and Ünal-Kesenci (2002) discuss China's role in the international segmentation of production process and found that China's specialization pattern has enhanced technological transfer, including through increased local content in its processing trade. Hiratsuka (2005) studies the "catching up" process of manufacturing in East Asia and finds that by 2001, China had advanced its catching up process (to the degree of becoming an exporter) mostly in nondurable goods and light machineries. Looking at more recent years, Gao and Ha (2006) note that China's trade structure has experienced large structural changes, with technologically sophisticated products such as machinery and transport equipments accounting for a growing share of exports, and more natural resource-based and high-tech products being imported.

This paper is also linked to previous work that stresses the importance of examining disaggregated data to better understand the factors driving trade patterns across countries (Feenstra and Rose (2000), Schott (2004), Hummels and Klenow (2005), and Schott (2006)). In particular, using product-level U.S. import data, Schott (2004) finds evidence consistent with specialization according to countries' factor endowments and technology within products, although there was no evidence of endowment-driven specialization across industries or even across products. This suggests that tests of trade theories using more aggregated data (at the industry level) may be problematic. In a more recent paper, Schott (2006) examines the relative sophistication of China's exports compared to OECD countries, and finds that although China exports more products in common with OECD countries than would be expected given its level of development, the prices it receives for its exports have been declining over time. Rodrik (2006) compiles sophistication indices for products based on the weighted averages of per capita GDP of the countries that export them, and finds that China's export bundle is more sophisticated than would be expected from its level of economic development, and has become more sophisticated over time. In these studies, the primary focus is on studying differences in trade composition across countries. Building upon this earlier work, especially the methodology proposed by Rodrik (2006) in measuring the sophistication level by products, we explore what shifting product composition might imply for China's aggregate trade over time.

The rest of the paper is organized as follows. Section II motivates the paper by discussing recent developments in China's trade and production structure. In particular, we discuss 
China's burgeoning trade surplus and argue that it is at least partly linked to a slowdown in intermediate imports that has not been matched by a commensurate slowdown in final exports. This suggests that the domestic content of China's exports may be increasing especially for products of lower technological sophistication and we provide some supporting evidence. In addition, we show that the export bundle has become more sophisticated over time, reflecting technological upgrade of domestic production; this in turn means that China now relies on more sophisticated imports for manufacturing. Motivated by these findings, Section III uses detailed trade data to conduct two separate sets of empirical analyses that allow us to formally test some of these hypotheses. The first part assesses the extent to which imports of intermediate products may have "delinked" from exports, as would be expected from rising domestic production capacity. The second part analyzes the shifting product mix of China's trade and, by exploring the cross-sectional variation in the response of trade flows of products of different degrees of sophistication to macroeconomic shocks, infers what this is likely to imply for trade elasticities going forward. Section IV concludes with a discussion of potential policy implications of the empirical findings, as well as some suggestions for future research.

\section{RECENT DEVELOPMENTS In CHINA's EXTERnAL TRADE}

China's trade surplus has expanded sharply recently - during the past five years, the trade surplus has grown over 5 folds in dollar terms and more than tripled as a percent of GDP. The most significant increase has occurred over the last three years, with China's trade surplus rising by over 5 percent of GDP. At end-2006, the trade surplus is estimated to have stood at around $\$ 215$ billion (BOP basis) or more than 8 percent of GDP. This expansion in the trade surplus reflects a sharp rise in the manufacturing trade surplus, with electronics, machinery, iron and steel, textiles and clothing, and organic chemicals the main contributors. ${ }^{3}$

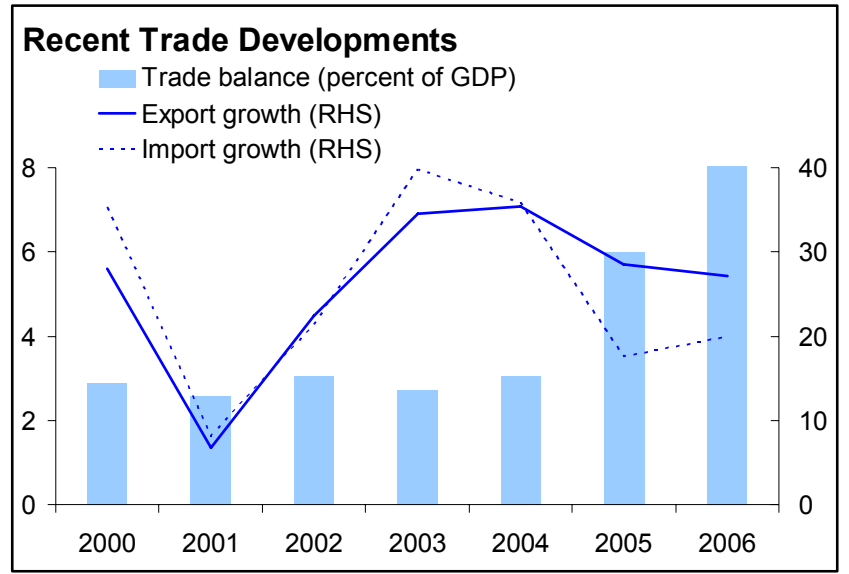

The rapid expansion in the trade surplus has mainly been driven by a significant slowdown in imports. Indeed, import growth started to lag export growth by large margins in early 2005, in contrast to the experience during most of the past decade where the growth rates of

\footnotetext{
${ }^{3}$ The trade balance in steel products, traditionally in deficit, moved into surplus for the first time in 2006.
} 
imports and exports tended to move together. Imports of intermediate goods slowed the most, with parts and components and semi-finished goods accounting for almost half of the slowdown in import growth between 2003 and 2006. This slowdown has had a direct impact on China's trade with the rest of Asia and may be altering its role in regional production chains. While its trade surplus with the U.S. and the EU

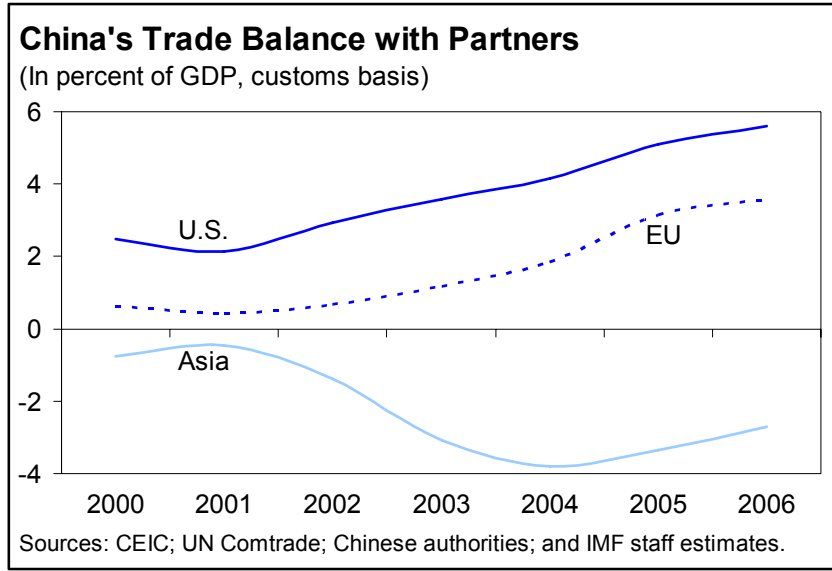
continues to grow, its trade deficit with the rest of Asia, traditionally an offset, has shrunk over the last two years. This has raised concerns in some Asian economies, especially those where exports to China have been an important driver of recent economic growth.

What explains this gap between the growth rates of imports and exports? And would it last? Understanding this is critical for predicting how the trade balance might evolve in future years. Some analysts have argued that the slowdown in import growth has been mainly driven by a temporary overinvestment in certain sectors and should reverse in due course as domestic demand picks up and excess capacity exhausts. Although we share the view that fluctuations in investment demand have played a role in the recent import slowdown, the continued strength of investment - albeit slowed compared to its peak - suggests that capacity is still being created at a rapid pace. Indeed, this paper argues that the increase in domestic capacity — supported by large investment and technological upgrade — was not a recent phenomenon and has been one of the key structural changes in China's economy over a number of years. In particular, domestic production capacity of a number of key intermediate products has risen several folds since 2000. Foreign direct investment has played an important role in this process, ${ }^{4}$ partly reflecting shifts in the global production network, with more stages of production shifting to China. Supported by the rising domestic production capacity, import content of exports has declined in many sectors: notably for home electrical appliances, ordinary machinery, and to a lesser extent, higher-tech products such as precision apparatus, exports of final products have continued to grow strongly, despite the recent slowdown in imports of intermediate inputs associated with their production.

\footnotetext{
${ }^{4}$ For example, FDI into the chemicals industry from the U.S. increased from around \$37 million in 1999 to $\$ 520$ million in 2005. Over the same period, FDI flows from Taiwan POC increased from \$538 million to $\$ 2.4$ billion in the electronics sector and from $\$ 28$ million to $\$ 373$ million in the precision instruments sector.
} 

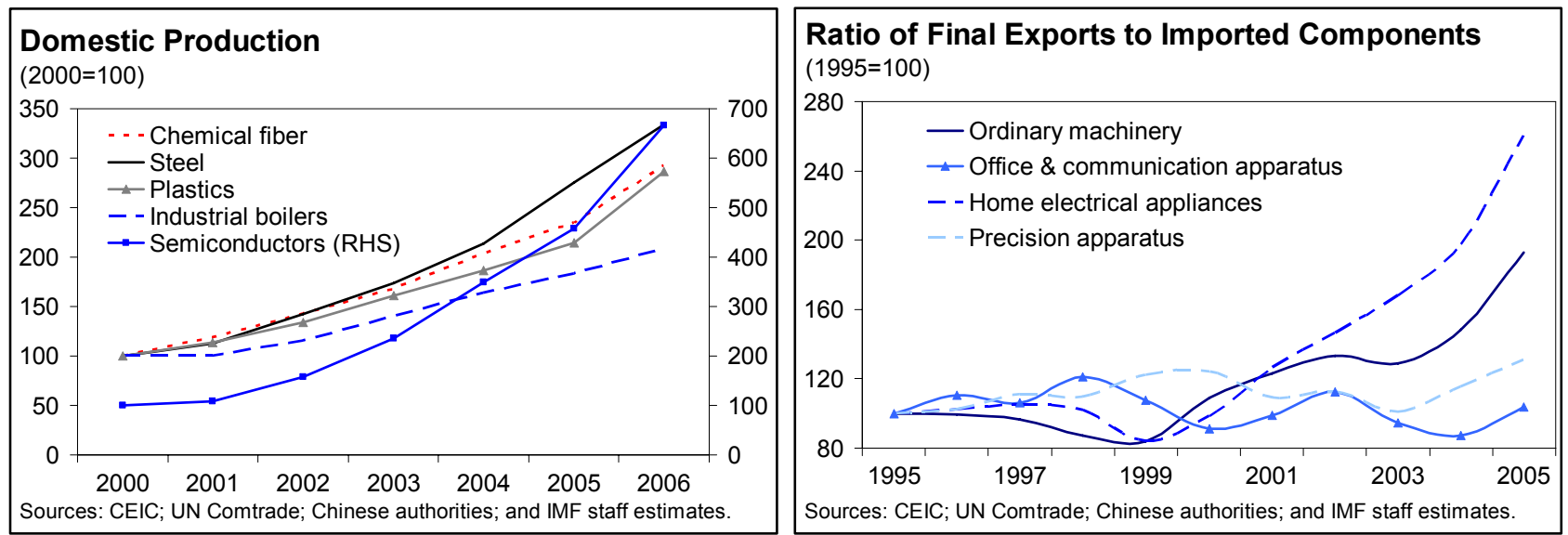

With the expansion of domestic supply, China's processing trade is increasingly shifting away from simple assembly operations toward those that have greater scope for using domestic inputs. The share of the former (dubbed "assembly operations" in China's official data) has declined sharply, accounting in 2006 for only about 10 percent of processing trade balance, down from more than 30 percent in the late 1990s. The latter, in contrast, has increased in importance and its margins - the domestic value added for each dollar exported, or the trade balance divided by exports - rose from the teens in the mid-1990s to more than 40 percent last year consistent with a greater use of domestic inputs.

The increase in production capacity and upgrade in technology also see significant changes in China's trade composition over the years. While labor-intensive consumption goods (including clothing, toys, etc.) used to dominate China's exports, their share in total exports has declined more than 20 percentage points over the past decade. Exports of capital goods and parts and components have risen sharply, accounting for more than 40 percent of total exports, compared to their share of 10-15 percent a decade ago. Such a shift at the broad economic sector level points to the changing trade and production structure in China toward more capital intensive and technologically advanced products.
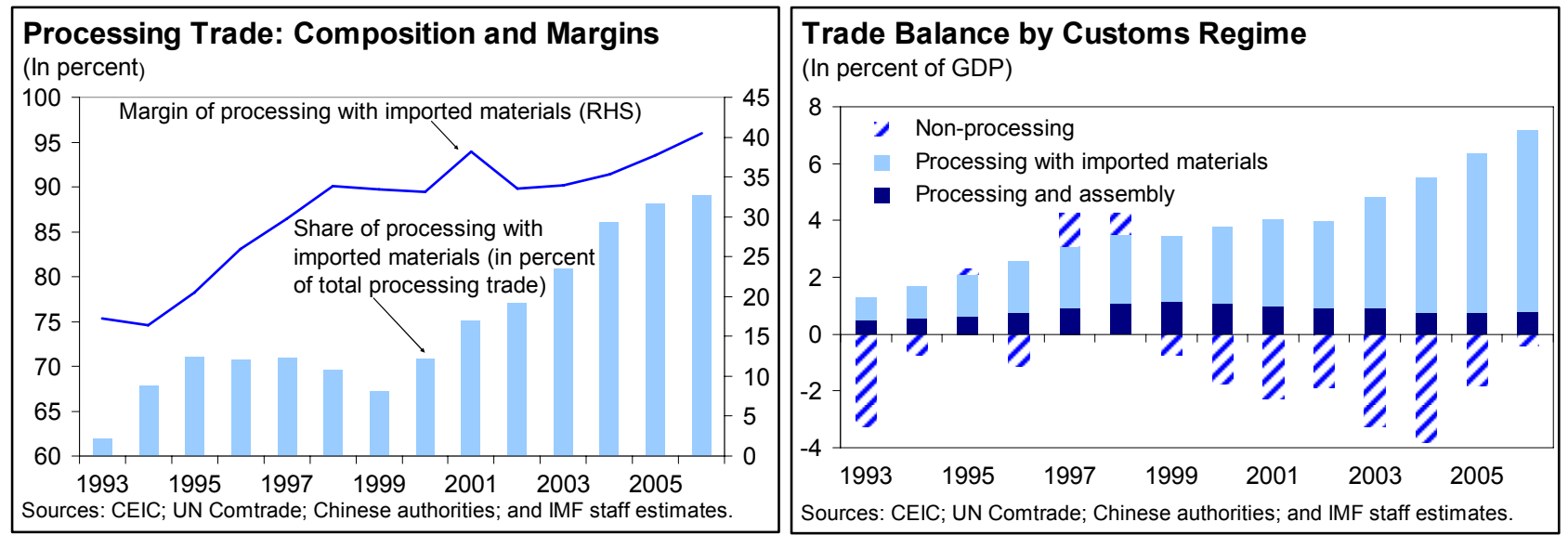
Measures of product sophistication for China's exports and import have risen significantly over the last decade. Not surprisingly, China tends to import more sophisticated goods than those it exports. ${ }^{5}$ The overall sophistication of China's exports has risen significantly over the last decade, while overall import sophistication has increased at a slower pace. The aggregate indices, nevertheless, may mask important sectoral differences: an examination of industrial sectors suggest that domestic production capability is near or even exceeding imported goods in intermediate products, such as manufacturing materials, chemicals, and nonfuel crude materials. This is consistent with the observation that the recent large investment in steel and chemicals have resulted in a vast expansion in domestic production capacity and a sharp slowdown in imports of these products. By contrast, for more sophisticated sectors, particularly electronics, China's production capability continues to lag behind imported goods, and the gap has not shown much sign of narrowing even after the large investment during 2003-04. As the gap is not narrowing, it appears that China is still some distance away from producing most of the required inputs for these more sophisticated final goods.

We then divide the products into three percentiles of sophistication: low-tech products correspond to the $30^{\text {th }}$ percentile or less of all products, medium-tech products fall between the $30^{\text {th }}$ and $70^{\text {th }}$ percentiles, and high-tech products are above the $70^{\text {th }}$ percentile. It turns out

\footnotetext{
${ }^{5}$ We adopt the "Rodrik index" to examine to what extent the imported products can be substituted with domestically-produced products. The indices are calculated as a weighted average of the sophistication indices across products, with the weights determined by trade shares (see Rodrik (2006) for details). The sophistication level of each product is measured by the weighted average of per capita GDP (PPP basis) of the countries that export this product, with the weights determined by the revealed comparative advantage of each country. While Rodrik calculated these indices for China's exports, he did not consider the product mix on the import side. For our purpose, we first calculate the sophistication index of China's exports. The range of products exported by China provides a measure of the production capability in the country. We then calculate the same index for China's imports. The comparison of the sophistication level between imports and exports provides one gauge of the technological feasibility of domestic sourcing.
}
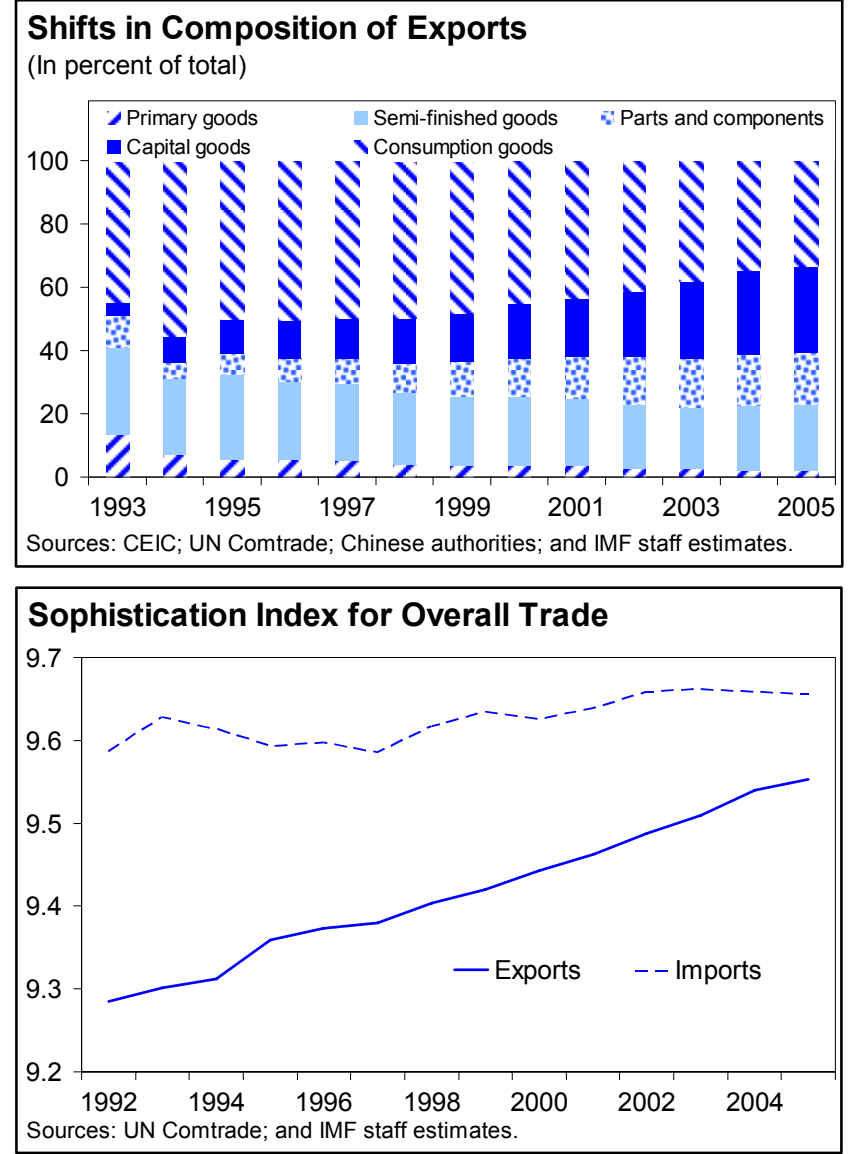
that on the export side, the greatest change has been an increase of high-tech products, whose share in total exports increased by 20 percent between 1995 and 2005 while the share of lowtech products declined by almost 20 percentage points. On the import side, the pattern is similar, although the changes are smaller. Today, high-tech products account for slightly less than 40 percent of China's total exports and more than 50 percent of its total imports.
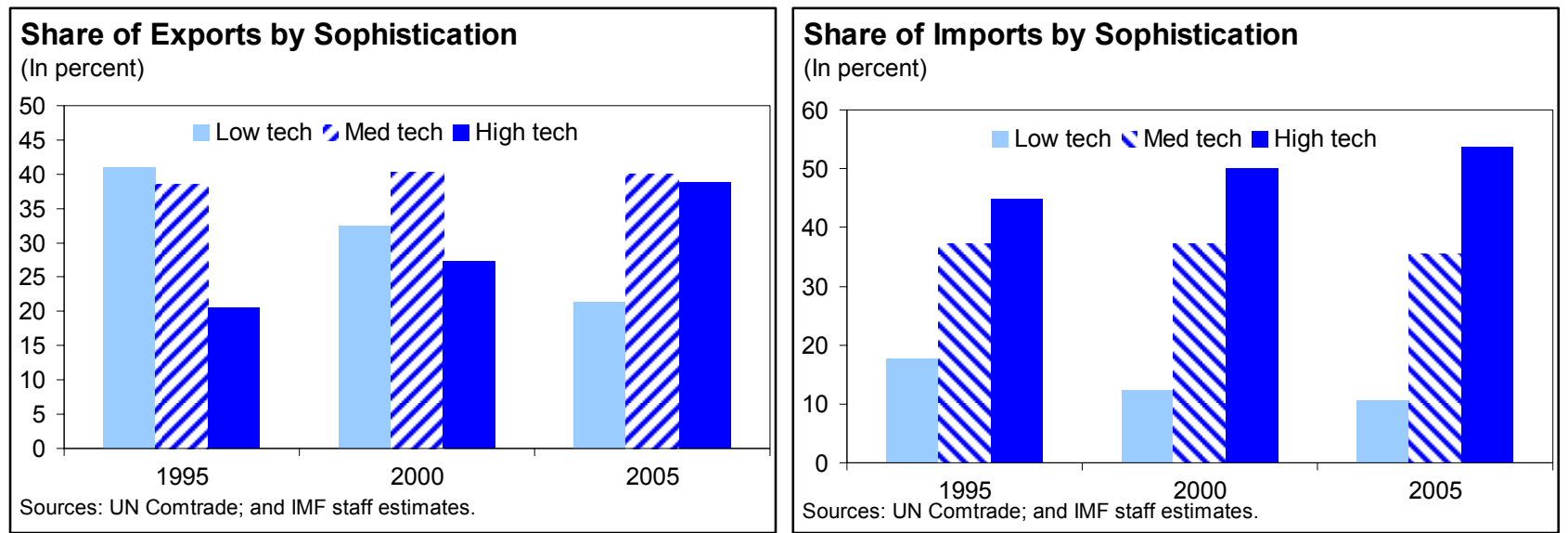

\section{Evaluating Trade Equations using Sectoral Data}

The response of trade flows to macroeconomic shocks is typically estimated by exploring the relationship between aggregate trade volumes and macroeconomic variables. Bayoumi (1999) is one example of how such estimation is performed. Along these lines, several papers have tried to estimate trade elasticities in China. Cerra and DayaFulaiti (1999) and Cerra and Saxena (2003) estimate the price elasticity of China's exports and suggest that exports have become more responsive to prices. Shu and Yip (2006) directly examine the impact of an exchange rate appreciation on China's trade balance and found that an appreciation can reduce exports by generating expenditure switching. Although it is generally accepted that China's economic structure is changing, for tractability of time series analysis and following the standard literature, these studies typically assume a stable relationship between aggregate trade flows and macroeconomic variables.

In this section, we explore how changes in China's production structure may have affected its trade flows and their responses to macroeconomic shocks over time. With significant structural changes, standard models based on aggregate data and assuming stable relations over time may yield inaccurate results. Two empirical tests are conducted. First, we examine the relationship between imports of parts and components, and exports of associated final products for a group of industries where these can be matched. Rising domestic production capacity should predict that the links of imports and exports in the same industry have weakened. This is borne out by our sample: we find that imports of parts and components have delinked from exports of final products in recent years. At the same time, imported inputs have become more strongly associated with domestic demand. 
Second, we examine the changes in the product composition of China's traded products and how product characteristics - in particular their sophistication level — may have affected the response of trade flows to aggregate shocks. We find that for more sophisticated products, both exports and imports are more sensitive to aggregate demand shocks, while exports are also more sensitive to real exchange rate changes. Given its rising sophistication level, it is possible, therefore, that China's aggregate trade has become increasingly sensitive to demand and price fluctuations, even without further price and trade regime changes (Cerra and DayaFulaiti (1999) attributed the increasing responsiveness of exports to prices during the 1980s and 1990s to these factors).

\section{A. The Delinking of Imports from Exports}

A central theme of this paper is that China's increasing domestic production capabilities may account for much of the slowdown in intermediate imports that has contributed to the rapid expansion in its trade surplus in recent years. In the absence of detailed production data that can be mapped to disaggregated trade data, this conjecture is hard to test directly. However, this hypothesis has other, potentially testable implications. In particular, it would be reasonable to expect that, at least in some sectors, this evolution in China's production structure may be diminishing the traditional role that foreign demand (through traditional processing trade with low domestic content) has played in determining trade patterns. Hence, we would expect that in those sectors, the intimate relationship that processing trade creates between imports of intermediate products (such as parts and components) and exports of associated final goods has weakened. At the same time, the role of domestic demand in determining import patterns could be increasing as China's economic structure evolves. In other words, imports and exports may be delinking in those sectors, with the consequence that macroeconomic shocks may have more potent effects on China's trade balance and its domestic economy.

\section{Data}

We use disaggregated trade data at the five-digit level based on SITC Revision 2, as reported in the UN Comtrade Database. Comtrade reports the nominal value of imports and exports on an annual basis between 1992 and 2005. A key requirement of our approach is the ability to relate imported intermediate products with specific final exports. Within the SITC classification system, we are able to directly relate 105 pairs of inputs and associated outputs within codes 7 (machinery and transport equipment), 87 (professional instruments) and 88 (photographic equipment). Together these account for, on average, around half of total imports of parts and components or roughly 15 percent of total imports over this time period. Due to this relatively limited coverage of China's imports, the trends we identify in our empirical work are not necessarily representative of manufacturing or processing trade as a whole. Nevertheless, they are suggestive and it is important to note that the dataset was not selected in any deliberate way. Rather, all the pairings of intermediate and final goods that were obviously possible using the SITC classifications and descriptions were included in our 
sample. ${ }^{6}$ Roughly a quarter of these pairs fall within the electronics sector, with the remaining falling under machinery and transport equipment. These import and export values are deflated using the SITC-specific U.S. import price indices, our proxy for world prices. Our estimate of domestic demand for the final product is derived by adding total manufacturing imports to total domestic industrial production (obtained from CEIC) and subtracting total manufacturing exports. We also experiment with some alternative measures, including estimates of domestic demand derived at the sectoral level as well as an aggregate measure of domestic demand from national accounts data. These measures of domestic demand are again deflated and expressed in real terms, using the manufacturing producer price index in China (obtained from CEIC) and the GDP deflator, respectively. Finally, we measure relative prices as the ratio between Chinese prices as captured by sectoral production price indices and world prices as proxied by U.S. sector-specific import price indices. This measure is also adjusted for changes in the RMB/USD exchange rate and tariff reductions that were implemented in China during this time period. Our panel is balanced and consists of data related to 105 imported parts over the period 1993-2005, for a total of 1,365 observations.

\section{Estimation}

As discussed in Section II, there is much anecdotal and indirect evidence of dramatic shifts in China's trade and production structure that would support the "delinking" hypothesis.

However, to formally test the hypothesis that final exports may have delinked from imported inputs in recent years, and that domestic demand may be playing an increasingly important role in determining import patterns, we considered the following regression:

$$
M_{i t}=\alpha+\beta X_{i t}+\phi D D_{i t}+\gamma\left(\frac{P_{i t}}{P_{i t}^{F}}\right)+\left(\eta_{i}+\varepsilon_{i t}\right)
$$

where $M_{i t}$ denotes imports of intermediate product $i$ at time $t$ (e.g., computer parts), $X_{i t}$ denotes exports of the final product associated with those imported inputs (e.g., computers) ${ }^{7}$, $D D_{i t}$ denotes domestic demand for that final product, and $\left(\frac{P_{i t}}{P_{i t}^{F}}\right)$ is a relative price term representing the price of the imported input in China relative to its world price. We allow the error term to have two components: a time invariant product specific-effect $\eta_{i}$ and a residual idiosyncratic error term $\varepsilon_{i t}{ }^{8}$ All variables, except for the relative price term, are deflated and

\footnotetext{
${ }^{6}$ A more detailed description of the dataset and summary statistics on the main variables are available upon request.

${ }^{7}$ In other words, foreign demand for the final goods produced with those inputs.

${ }^{8}$ In our empirical work, we also allow for the presence of time-specific effects.
} 
measured in real terms. If foreign demand is an important determinant of import patterns (as implied under conventional processing trade, i.e., pure assembly with minimal local content), we would expect the coefficient on the export variable $\beta$ to be positive. Similarly, if imports are associated with domestic demand (as one would normally expect in an economy where pure assembly operations account for a small part of trade), $\phi$ should be positive. In addition to their signs, we will be interested in the evolution of the magnitude these coefficients over time, to assess whether the strength of the relationship between imports and foreign demand on the one hand, and domestic demand in China on the other, has changed. At the same time, higher relative prices in China should be associated with an increase in imports, so that we expect $\gamma$ to be positive. Notice that alternative assumptions about the properties of the error term $\left(\eta_{i}+\varepsilon_{i t}\right)$ will determine which econometric methodology is likely to be most appropriate. Accordingly, in our empirical work, we will present results using a range of estimation procedures and assess their robustness across alternative specifications.

\section{Results}

In Table 1, we begin by estimating the model given in (1) in logs on the full sample, which allows us to interpret estimated coefficients on our regressors as elasticities. All standard errors reported in this section are robust to heteroskedasticity. Column 1 presents some simple pooled OLS results, and while we find all three regressors to be correctly signed, only exports are significant. However, in the presence of product-specific effects, the OLS estimator would be inefficient and potentially inconsistent. In column 2, we allow for uncorrelated individual effects, and use the random effects estimator. These estimates have smaller standard errors, suggesting some gain efficiency by allowing for product-specific effects. Moreover, all three regressors are correctly signed and highly significant. However, the random effects model is rejected by the Hausman test at the 1 percent level. In column 3 , therefore, we allow the product-specific effects to be correlated with our regressors and estimate the model using the fixed effects estimator. The parameter estimates are close to those in column 3, and all regressors are highly significant. ${ }^{9}$ However, we found evidence of first-order serial correlation in the residuals in this specification. Finally therefore, in column 4, we estimate the model using first-differenced OLS, another transformation that eliminates the time-invariant product-specific effects. ${ }^{10,11}$ While diagnostic tests could not

\footnotetext{
${ }^{9}$ Under the classical assumptions, and allowing for correlated product-specific effects, the fixed effects estimator is consistent. In addition, since our dependent variable and regressors display significant time series ('within') variation, it is also likely to be efficient.

${ }^{10}$ In addition to being consistent under weaker assumptions, the first-differenced OLS estimator would be more efficient than the fixed effects estimator if the classical assumption that the idiosyncratic error term $\varepsilon_{i t}$ is serially uncorrelated is invalid and it follows a random walk process instead.

${ }^{11}$ Notice that this transformation also forces us to lose the first year of our panel, so that the sample is slightly smaller (1,260 observations between 1994 and 2005).
} 
formally reject the hypothesis that our log export and import variables do not have unit roots, there is some concern about their power in panels. In this context, a further advantage of the first-differencing transformation is that it could induce stationarity and thus control for any unit (or near unit) roots in our panel. We find that all three regressors are again correctly signed and highly significant. The robustness of our basic results across different panel estimation strategies is encouraging, and for most of the rest of this section we will concentrate on presenting results using our preferred fixed effects and first-differenced OLS estimators.

In Table 2, we present some sub-sample results where we divide our sample by time period. We will be testing whether there is any evidence of heterogeneity in our parameter estimates across these sub-samples, and in particular whether the relationship between imported inputs, associated final exports and domestic demand has changed in the more recent time period. Columns 1 to 3 report results using the fixed effects estimator on the model in log levels. Column 1 reestimates the model presented in column 3 of Table 1, omitting the first year of our dataset. This allows us to decompose the sample into two equal six year time periods, i.e., 1994-1999 and 2000-2005, with both sub-samples consisting of 630 observations. While the standard errors are understandably larger in column 1 than those in column 3 of Table 1, the parameter estimates are not significantly different and confirm our earlier conclusions. However, the two sub-samples display markedly different properties. In particular, while the coefficient on exports is highly significant and of similar magnitude in both time periods, the estimated coefficient on domestic demand displays significant heterogeneity. While its coefficient is insignificantly different from zero in the earlier period, it is both highly significant and much larger in the latter period. Relative prices remain correctly signed and significant across the sub-samples. The point estimates on exports and domestic demand are more than three standard deviations away across sub-samples, and more formal tests of parameter heterogeneity also strongly reject the hypothesis that these coefficient estimates are the same across the two time periods. Columns 4 to 6 repeat the same specifications using the first-differenced OLS estimator, which is more appropriate due to the presence of first-order serial correlation in the residuals of the fixed effects model. The results are robust to this alternative estimation strategy, with evidence of significant parameter heterogeneity across our sub-samples. Indeed, they are even starker in this formulation: with the coefficient estimates suggesting that in a reversal of earlier patterns, in recent years domestic demand growth has become strongly associated with, and export growth completely disassociated from, import growth. ${ }^{12,13}$ In other words, conditional on

\footnotetext{
${ }^{12}$ We experimented with a variety of alternative domestic demand and relative price variables, including real GDP, sector-specific derived domestic demand, the real effective exchange rate and aggregate relative prices for the manufacturing and machinery sector as a whole, and found the results to be robust.

${ }^{13}$ We obtained qualitatively similar results as those reported in Tables 1 and 2 using sector-specific domestic demand variables that varied across products and including dummies to control for time-effects, although the explanatory power of our regressions was generally lower.
} 
domestic demand, fluctuations in final exports convey no information relevant for explaining imported intermediate inputs in the latter half of our sample. This is not what one would expect under the conventional view of China as no more than a large assembly plant, under which imports and exports should be closely associated.

Finally, we present some additional robustness checks on these basic results in Table 3. In particular, we reestimate the specifications presented in Table 2 while allowing the domestic demand variable to be endogenous by using an IV estimation strategy. We instrument our measure of aggregate derived domestic demand with real domestic credit. As the table shows, our results are robust to this alternative empirical strategy, with the coefficient estimates closely resembling those in Table 2, no evidence of weak instruments, and a Hausman test not rejecting the validity of the IV model in log levels. ${ }^{14}$

Taken together, our results suggest that within our sample, imports have delinked from exports, and have become more responsive to domestic demand in recent years. These findings are consistent with the hypothesis that the role of foreign demand in determining import patterns in China has diminished in recent years and that domestic (production and consumption) needs are becoming more relevant, much as you would expect in a typical economy with limited processing trade. Interestingly, we found weaker evidence of parameter heterogeneity across time within the electronics sub-sector of our sample. This suggests that the relative sophistication of the technology embodied in various sectors may also be an important determinant of the pace at which exports could be delinking from imports in China, a hypothesis that is explored further in the next section.

\section{B. Product Sophistication and Trade Flows}

This section directly tests the hypothesis that China's changing production and trade structure is an important factor affecting its aggregate trade. The "sophistication index" discussed earlier provides a useful measure to capture the structural change at the detailed product level. In the following analysis, we examine whether products of different technical sophistication level tend to respond differently to foreign and domestic demand, and to the fluctuation in the trade-weighted real exchange rate. If so, in a fast changing economy such as China, the reaction of aggregate imports and exports to macroeconomic shocks may change over time simply because the changes in the product composition, even if everything else is held still.

It is conceivable that exports and imports of products with different sophistication level react differently to aggregate demand shocks and exchange rate changes. Analysis in the previous

\footnotetext{
${ }^{14}$ We experimented with other instruments for domestic demand, including lagged values and domestic demand estimated from National Accounts Data, as well as treating the export variable to also be endogenous and instrumenting it with its own lags, and found similar results.
} 
section suggests that China is improving its production technology and starts to source more inputs domestically rather than imports. The less sophisticated a product it is, the easier it may be to find comparable domestic substitute. Thus imports of more sophisticated products could be more responsive to a change in domestic demand, while the rising capacity enables greater import substitution at the lower end. For the same reason, imports of more sophisticated products could be less responsive to relative price changes than imports of those at the lower end. On the export side, sophisticated goods could be more responsive to foreign demand changes than more basic goods (the "luxury" goods effect). Sophisticated goods could be more (or less) responsive to exchange rate changes, if producers of these goods have less (or more) pricing powers in the world market. While we do not explore these reasons explicitly, the empirical results from the estimation may help shed lights on these factors.

\section{Data}

We estimate a panel of trade equations for product groups represented by the five-digit categories in SITC $2^{\text {nd }}$ revision during 1993-2005, taking into account the "sophistication levels" of these products. Agricultural and miscellaneous products are excluded for the analysis (thus the dataset includes all products corresponding to the two-digit SITC $2^{\text {nd }}$ revision between 21 and 89). We choose two specifications for exports and imports. In the first specification, exports and imports correspond to trade volumes. In the second specification, exports and imports are dollar-denominated trade value, divided by China's dollar GDP. The trade volume and trade value data are all obtained from the UN Comtrade Database. We use normalized trade value as the dependent variable in the second specification in order to improve our data coverage. For about 6 percent of the observations during the sample period, Comtrade reports value but not volume data. The missing values appear to occur randomly over time, for instance, some products could be associated with positive volumes for some years while missing volumes for other years, even if values are positive for all years. This problem is compounded when the estimation is based on the growth of volume, resulting in more than 10 percent shrinkage of the sample size. Trade value as a share of GDP thus provides more comprehensive coverage for the sample. In addition, export and import shares in percent of GDP are of some direct interest to researchers who study the link of trade and current account as shares of GDP and changes in demand and exchange rates. ${ }^{15}$

\section{Estimation}

To start, the first set of trade equations are specified as:

$x_{i, t}=a_{1}+a_{2} f d_{t}+a_{3} r e r_{t}+a_{4} s_{i}+a_{5} s_{i}^{*} f d_{t}+a_{6} s_{i} * \operatorname{rer}_{t}+\alpha_{i}+\chi_{t}+\varepsilon_{i, t}$

${ }^{15}$ Lee and Chinn (2002) provide one example of such studies. 
for exports, and

$m_{i, t}=b_{1}+b_{2} d d_{t}+b_{3} s_{i}+b_{4} f d_{t}+b_{5} r e r_{t}+b_{6} s_{i} * d d_{t}+b_{7} s_{i} * r e r_{t}+\beta_{i}+\gamma_{t}+v_{i, t}$

for imports.

$x_{i, t}$ and $m_{i, t}$ represent export and import volume, respectively for product $i$ and year $t . d d_{t}$ is the real domestic demand at year $t$, calculated as the nominal domestic demand divided by the level of producer prices. Nominal domestic demand is calculated as the difference of industrial production and trade balance. $f d_{t}$ is the level of external demand, calculated as the real GDP of China's trading partners weighted by their importance in the trade with China. ${ }^{16}$ rer $_{t}$ is China's trade weighted real effective exchange rate. All of these variables are in first difference of logarithm. $s_{i}$ is an index that represents the sophistication level of product $i$, which takes on three values of 0,1 and 2 , corresponding to "low tech", "medium tech", and "high tech" as described in Section II. $s_{i}$ varies by product but not over time. $\alpha_{i}$ and $\beta_{i}$ are cross-sectional fixed effects for export and import equations of product $i$, to control for product specific characteristics, and $\chi_{t}$ and $\gamma_{t}$ are time effects for export and import equations of time $t$ to control for time specific shocks. In particular, the inclusion of time effect $\chi_{t}$ and $\gamma_{t}$ allows for the possibility that some time varying variables that are relevant for exports and imports (such as real interest rate) may be missing from the simple specification of (3) and (4). The variable $f d_{t}$ is included in the import equation to capture the impact on China's imports from exports through the processing trade, above and beyond the impact of other variables included in the regression. $\varepsilon_{i, t}$ and $v_{i, t}$ are idiosyncratic errors that are independently and identically distributed across products and years.

We include interaction terms $s_{i} * d d_{t}$ in the import equation and $s_{i} * f d_{t}$ in the export equation, and $s_{i}{ }^{*}$ rer in both equations. Therefore, income elasticity of exports for product $i$ is $a_{2}+a_{5} s_{i t}$, exchange rate elasticity of exports for product $i$ is $a_{3}+a_{6} s_{i}$. Similarly, income elasticity of imports for product $i$ is $b_{2}+b_{6} s_{i}$, and exchange rate elasticity of imports for product $i$ is $b_{5}+b_{7} s_{i}$. As our main interest is how the product sophistication may affect the elasticities rather than the absolute size of the elasticities, we focus on the significance, sign and magnitude of parameters $a_{5}, a_{6}, b_{5}$, and $b_{7}$. One or several statistically significant coefficients on these interaction terms would suggest that products react differently for a

\footnotetext{
${ }^{16}$ Alternatively, we use world import for sector $i$ (normalized by other countries' GDP). Such a specification enhances the power of the regression significantly as seen from a much higher $\mathrm{R}^{2}$. The associated coefficients are related to penetration of China's products in the world market. Such penetration is larger for less sophisticated products.
} 
given macroeconomic shock. For countries where trade structure is undergoing significant changes over time, trade elasticities at the aggregate level must have shifted over time. It is worth noting that we have abstracted from an estimation of the average income and exchange rate elasticity across products in the above exercise, and only focus on how such elasticities may be different across products. For instance, using aggregate date, Shu and Yip (2006) demonstrated that at an aggregate level, export increases when foreign demand increases, and decreases when the real effective exchange rate appreciates. This can be considered as our benchmark for the "average elasticity" of exports.

The second set of equations are the same as (3) and (4) except that the dependent variables are nominal value of exports and imports of product $i$ at year $t$ as shares of China's annual GDP. The first differences of logs in $d d_{t}, f d_{t}$, and $r e r_{t}$ are replaced by the annual growth of the level variables. Again, our main interest is the coefficients on the interaction terms $a_{5}, a_{6}$ and $b_{5}, b_{7}$. However, given that this specification is less commonly used than the equations of trade volumes, we also estimate the model without the time effect and interaction terms, to establish the links of the variables. We then include the interaction terms to test the significance of $a_{5}, a_{6}$ and $b_{5}, b_{7} \cdot{ }^{17}$

\section{Results}

Table 4 and Table 5 report the estimation results for the first specification. We focus on the coefficients on the interaction terms: $a_{5}, a_{6}$ and $b_{6}, b_{7}$. Since our regression contains crosssection and time fixed effects, those variables that are constant across observations ( $d d_{t}, f d_{t}$, and $\left.r e r_{t}\right)$ or those variables that are constant over time $\left(s_{i}\right)$ drop from the regressions. Robust estimates of the standard errors are reported.

In the export equation, the more sophisticated a product is, the more its exports tend to increase in response to a given increase in foreign demand, and the more its exports tend to drop for a given appreciation of the real effective exchange rate. Both $a_{5}$ and $a_{6}$ are statistically significant at the 5 percent level. In the import equation, the more sophisticated a product is, the more its imports tend to increase in response to a rise in domestic demand, although it tends to increase less (or decrease more) in response to a given appreciation of the real effective exchange rate. However, while $b_{6}$ and $b_{7}$ are individually significant (i.e., when the other interaction term is not included in the regression), $b_{6}$ becomes insignificant when both are included in the regression. We reestimate the model for the period 1994-2002, excluding the most recent period with the significant investment boom, which may have

\footnotetext{
${ }^{17}$ The coefficients reported in Table 6 and Table 7 do not include the time effects. Including time effects in the regressions yields very similar results.
} 
weakened some of the relations. We find both interaction terms become statistically significant.

Table 6 and Table 7 report the estimation results from the second specification. ${ }^{18}$ The first column in Table 6 and Table 7 estimates (3) and (4) without the interaction terms. The baseline suggests that import-to-GDP ratio increases when domestic demand and foreign demand increases, and when there is a real appreciation in the exchange rate, and export-toGDP ratio rises when foreign demand increases and when there is a real depreciation.

We then add the interaction terms as discussed above. The coefficients of the interaction terms $a_{5}, a_{6}$ and $b_{6}, b_{7}$ are reported in the second to fourth column. On the export side, similar to the first specification, the more sophisticated a product is, the more export as a share of GDP will drop for a given appreciation of the real effective exchange rate. While export-to-GDP increases more in response to a rise in foreign demand for more sophisticated products, the coefficient is not statistically significant. On the import side, again, the more sophisticated a product is, the more the import-to-GDP ratio tends to increase in response to a rise in domestic demand, and the coefficient $b_{6}$ is significant at the 5 percent level. The response of the import-to-GDP ratio to a change in exchange rate is not statistically significant when both interaction terms are included in the regression.

In both specifications, the response of exports to a change in real effective exchange rate is found to be affected by the sophistication of the products. The more sophisticated a product is, the more its exports (volume or the share to GDP) tend to decline for a given appreciation in the real effective exchange rate. This may reflect the fact that producers of more sophisticated products have less pricing power in the world market, and therefore are less able to pass through the exchange rate changes to the foreign market. There is also evidence that income elasticity of export is greater for more sophisticated goods. This is consistent with the fact that exports of China have moved toward more investment goods which tend to fluctuate more with foreign economic cycles (Dark and Hawkins (2005)) and that more sophisticated consumer goods tend to have higher income elasticity than necessary goods. Results on the import side suggest imports of more sophisticated products respond more to domestic demand changes. The results are both statistically significant for import volume for the sample period before the recent investment boom, and for import-to-GDP ratio for the full sample. This is consistent with the notion that import substitution is greater at the lower end of technological sophistication with improved domestic production capacity and an increase in demand tends to be met by domestic production than being imported, while demand for more sophisticated products tends to be met by imports. There could also be

\footnotetext{
${ }^{18}$ Panel unit root tests reject the hypothesis that the dependent variables export and import to GDP ratios have unit roots.
} 
"luxury goods" effect where high-end products are associated with higher income elasticity. However, the fact that such effect becomes weaker when the recent period of high investment is included suggests domestic production capacity that enables import substitution might be a more relevant explanation. Imports of more sophisticated goods tend to increase less for a given appreciation in the real exchange rate, possibly driven by the fact that many of the sophisticated products still cannot be produced at home and therefore less responsive to a change in the exchange rate. The coefficient, however, becomes statistically insignificant in the specification of import-to-GDP ratio.

\section{Conclusion}

This paper shows that significant shifts have taken place in China's production and trade structure over the last decade. In particular, the traditional tight link between imports and exports created by processing trade may be weakening as a result of increased domestic production capabilities supported by large FDI inflows. Moreover, product composition has shifted significantly for both exports and imports, as China has continued to upgrade its production capability while demanding increasingly more sophisticated products from abroad. The delinking of China's trade bundle and the shift toward more high-end products implies that China's exports and trade balance could become more sensitive to foreign demand and relative price changes than in the past. These results cast doubt on traditional views about China's trade structure. This new structure, in turn, gives rise to a number of interesting implications that challenge conventional wisdom both about the vulnerabilities of the Chinese economy and its role and influence in the broader regional context.

In terms of implications for China's own economy, our results suggest that its trade balance may have become more sensitive to external shocks such as shifts in global demand or exchange rates than commonly assumed. This underscores the need to hasten the rebalancing of China's growth, away from potentially volatile net exports that are increasingly vulnerable to exchange rate and demand shifts toward a more sustainable path driven by domestic demand. ${ }^{19}$ The next step in this line of research could be to take these shifts in production and trade structure into account while undertaking empirical analysis with aggregate data, perhaps by allowing for structural breaks and various forms of instability such as heterogeneity based on sophistication, in estimated trade equations.

\footnotetext{
19 The corollary to this is that equilibrium exchange rate analyses based on estimated trade dynamics may have overestimated the extent of renminbi undervaluation. While it may be true that the renminbi is undervalued, and this paper does not address this question as noted earlier, it is likely that the results of such exercises have been driven by the caricature about China's trade. Since in all these exercises, undervaluation is defined as the amount of relative price (in this case the exchange rate) changes alone needed to reduce the trade balance to a particular level, relative prices have to obviously move a lot because they have a small estimated effect on the trade balance to begin with.
} 
This new paradigm could also have important regional implications in terms of intra-Asian trade flows and the evolution of regional production networks. In recent years, China has displaced the U.S. as the largest export market for an increasing number of Asian countries and been pivotal in boosting intra-regional trade and FDI, particularly in the form of intermediate goods channeled through multinationals as part of cross-border chains. Indeed, intermediate products account for almost three-fifths of the increase in intra-regional trade within Asia over the last decade. However, as China begins to specialize in more parts of this production chain, its imports of intermediate goods from the region could start to fall. On their own, these trends could decrease intra-regional trade linkages. However, the potential expansion of China's domestic market create new opportunities for regional economies, particularly in terms of higher-tech products that China is unlikely to be able to produce domestically in the near future. These developments thus highlight the need for regional economies to advance their technological innovation and move up the quality chain. At the same time, to the extent that China's comparative advantage evolves and its labor costs rise as a consequence, this could present an opportunity for the lower-income countries in Southeast Asia to take China's place at the lower end of these networks.

In global markets, while China's rapidly expanding domestic demand is commonly held as a major factor in driving up the price of primary commodities, notably oil, it could be moving rapidly from being a price taker to a price setter for intermediate goods. Hence, just as it has helped to hold down the price of unskilled labor and labor-intensive manufacturing goods, it might start to exert a further dampening influence on global inflation through its effects on the supply (and hence price) of intermediate goods. A closer examination of the implications of China's shifting production and export structure for regional production networks and prices in global markets would seem to be a fruitful area for further research. 
Table 1. Testing Delinking of Imports and Exports: Full Sample, Alternative Specifications

\begin{tabular}{|c|c|c|c|c|c|c|c|c|}
\hline & \multicolumn{2}{|c|}{$\begin{array}{l}\text { OLS } \\
\text { (1) }\end{array}$} & \multicolumn{2}{|c|}{$\begin{array}{c}\text { Random Effects } \\
\text { (2) }\end{array}$} & \multicolumn{2}{|c|}{$\begin{array}{l}\text { Fixed Effects } \\
\text { (3) }\end{array}$} & \multicolumn{2}{|c|}{$\begin{array}{c}\text { First differences } \\
\text { (4) }\end{array}$} \\
\hline & coef & se & coef & se & coef & se & coef & se \\
\hline $\ln \quad X_{i t}$ & $0.544^{* *}$ & 0.056 & $0.307^{* \star}$ & 0.024 & $0.268^{* *}$ & 0.025 & $0.084^{* *}$ & 0.020 \\
\hline In $D D_{i t}$ & 0.071 & 0.102 & $0.372^{* *}$ & 0.047 & $0.419^{\star *}$ & 0.048 & $0.655^{\star *}$ & 0.164 \\
\hline $\ln \left(\frac{P_{i t}}{P_{i t}^{F}}\right)$ & 0.297 & 0.247 & $0.496^{* *}$ & 0.124 & $0.540^{\star *}$ & 0.124 & $1.098^{* *}$ & 0.245 \\
\hline Constant & $4.165^{\star}$ & 1.902 & 1.766 & 0.921 & 1.445 & 0.909 & -0.018 & 0.033 \\
\hline Number of observations & \multicolumn{2}{|c|}{1365} & \multicolumn{2}{|c|}{630} & \multicolumn{2}{|c|}{630} & \multicolumn{2}{|c|}{1260} \\
\hline Number of products & \multicolumn{2}{|c|}{105} & \multicolumn{2}{|c|}{105} & \multicolumn{2}{|c|}{105} & \multicolumn{2}{|c|}{105} \\
\hline R2_overall & \multicolumn{2}{|c|}{0.43} & \multicolumn{2}{|c|}{0.40} & \multicolumn{2}{|c|}{0.39} & \multicolumn{2}{|c|}{0.03} \\
\hline R2_within & & & 0. & & & & & \\
\hline \multirow[t]{2}{*}{ R2_between } & & & 0. & & & & & \\
\hline & \multicolumn{8}{|c|}{ Rejected by Hausman test $1 /$} \\
\hline
\end{tabular}

1/ Null hypothesis for the Hausman test is that the coefficients in the fixed-effects and random-effects specifications are not systematically different. A rejection of the null implies that the random effects are correlated with the other regressors, and hence the estimates from the random-effects specification are biased. 
Table 2. Testing Delinking of Imports and Exports: Sub-Sample Analysis

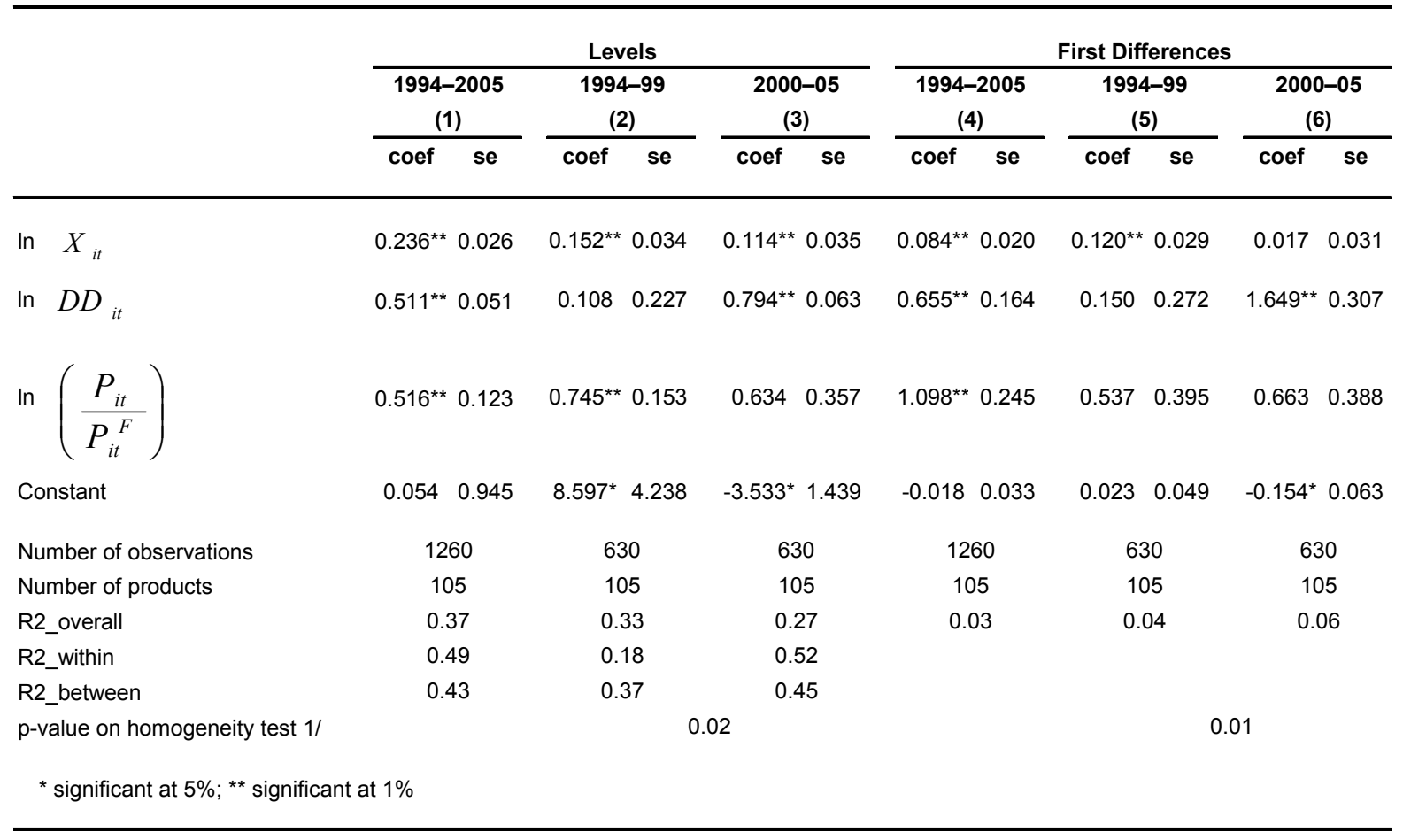

$1 /$ Null hypothesis for the parameter homogeneity test is that the coefficients in the two sub sample regressions are not systematically different. 
Table 3. Robustness Checks: Sub-Sample Analysis Using IV Estimation 1/

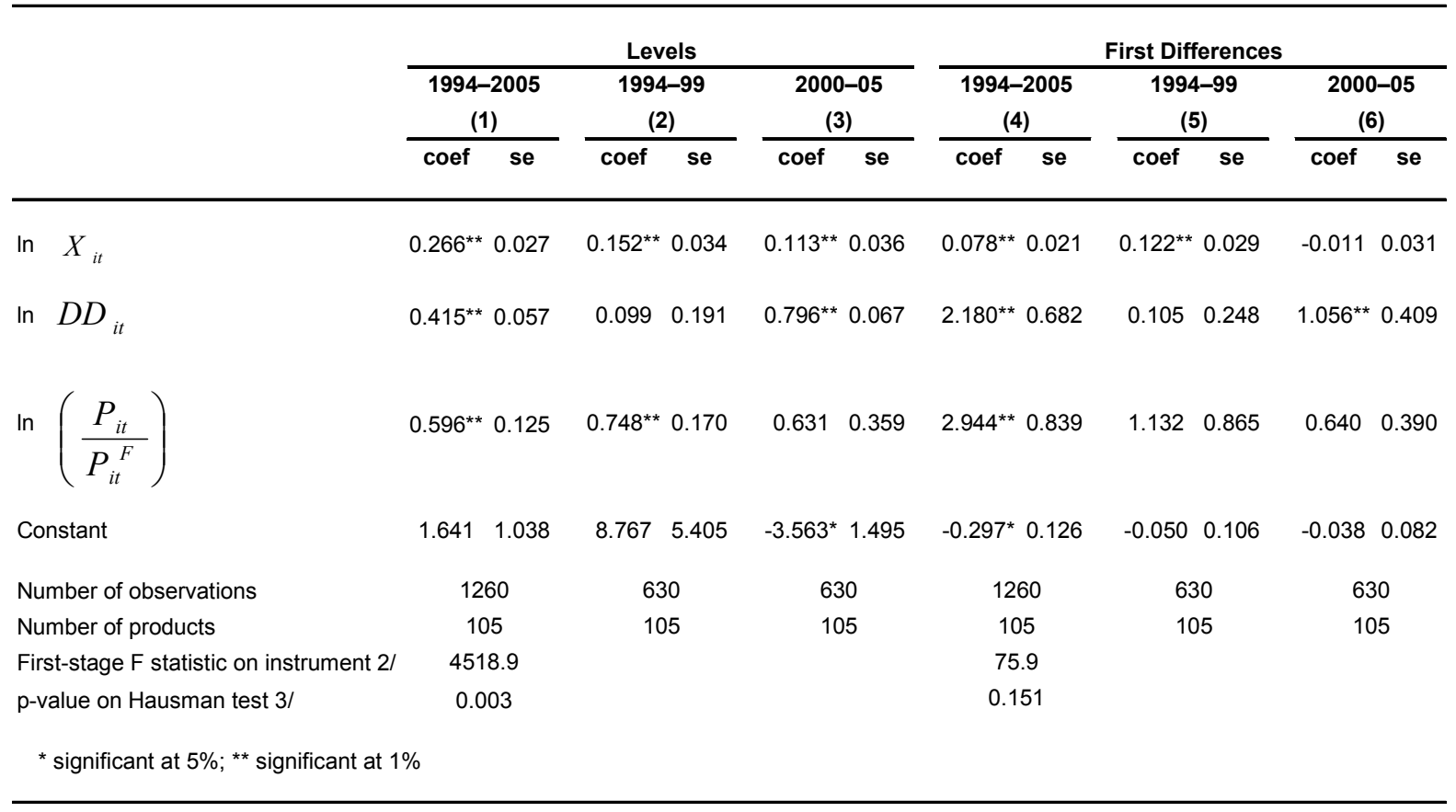

$1 /$ Domestic demand (DD) is instrumented with domestic credit in these specifications.

2/ R-squareds are not reported as they do not have the standard interpretation.

3/ First-stage F-statistic tests for weak instruments, under the null hypothesis that the coefficients on the instruments are zero.

4/ Null hypothesis for the Hausman test is that the coefficients in the fixed effects/first differenced and IV regressions are not

systematically different. A rejection of the null implies that the fixed effects/first differenced estimate is biased. 
Table 4. Export Elasticities and Product Sophistication Level 1/

\begin{tabular}{|c|c|c|c|c|c|c|c|c|c|c|c|c|}
\hline & \multicolumn{6}{|c|}{ Sample Period: 1994-2005 } & \multicolumn{6}{|c|}{ Sample Period: 1994-2003 } \\
\hline & \multicolumn{2}{|c|}{$\begin{array}{l}\text { Demand } \\
\text { Interaction } \\
\text { Only }\end{array}$} & \multicolumn{2}{|c|}{$\begin{array}{c}\text { Exchange Rate } \\
\text { Interaction } \\
\text { Only }\end{array}$} & \multicolumn{2}{|c|}{$\begin{array}{c}\text { Both Demand } \\
\text { and Exchange } \\
\text { Rate } \\
\text { Interactions }\end{array}$} & \multicolumn{2}{|c|}{$\begin{array}{c}\text { Demand } \\
\text { Interaction } \\
\text { Only }\end{array}$} & \multicolumn{2}{|c|}{$\begin{array}{c}\text { Exchange Rate } \\
\text { Interaction } \\
\text { Only }\end{array}$} & \multicolumn{2}{|c|}{$\begin{array}{c}\text { Both Demand } \\
\text { and Exchange } \\
\text { Rate } \\
\text { Interactions }\end{array}$} \\
\hline & coef & se & coef & se & coef & se & coef & se & coef & se & coef & se \\
\hline dln_FD x SL (a5) & $1.7^{\star \star}$ & 0.75 & & & $1.6^{* *}$ & 0.75 & $2.1^{\star *}$ & 0.86 & & & $2.1^{* *}$ & 0.86 \\
\hline dln_RER $\times$ SL (a6) & & & $-0.3^{*}$ & 0.18 & $-0.3^{*}$ & 0.18 & & & $-0.5^{*}$ & 0.24 & $-0.5^{*}$ & 0.24 \\
\hline _cons & $0.2^{\star \star *}$ & 0.04 & $0.3^{* * *}$ & 0.03 & $0.2^{* * *}$ & 0.04 & $0.1^{\star \star *}$ & 0.04 & $0.3^{* * *}$ & 0.04 & $0.2^{\star \star *}$ & 0.05 \\
\hline Number of observations & \multicolumn{2}{|c|}{17,320} & \multicolumn{2}{|c|}{17,320} & \multicolumn{2}{|c|}{17,320} & \multicolumn{2}{|c|}{12,903} & \multicolumn{2}{|c|}{12,903} & \multicolumn{2}{|c|}{12,903} \\
\hline Number of Sectors & \multicolumn{2}{|c|}{1,528} & \multicolumn{2}{|c|}{1,528} & \multicolumn{2}{|c|}{-0} & \multicolumn{2}{|c|}{1,523} & \multicolumn{2}{|c|}{1,523} & \multicolumn{2}{|c|}{1,523} \\
\hline $\mathrm{R} 2$ & \multicolumn{2}{|c|}{0.01} & \multicolumn{2}{|c|}{0.01} & \multicolumn{2}{|c|}{0.01} & \multicolumn{2}{|c|}{0.01} & \multicolumn{2}{|c|}{0.01} & \multicolumn{2}{|c|}{0.01} \\
\hline
\end{tabular}

1/ The dependent variable is the log first differenced exports. The regressors are log first differenced real effective exchange (dln_RER) log first differenced foreign demand level (dln_FD), and interaction terms with the product sophistication level (SL). SL is represented by the dummy variables that describes the product as "low tech", "medium tech", or "high tech", as discussed in the text. The regression is performed at the five-digit level of SITC 2nd revision for all products excluding agricultural goods. Robust standard deviation is reported in the table. The model includes fixed effects for the cross sections and time effects for years. The observations include nonagricultural and non-miscellaneous products, corresponding to products with the first two digit SITC code less than 90 and greater than 20. 
Table 5. Import Elasticities and Product Sophistication Level 1/

\begin{tabular}{|c|c|c|c|c|c|c|c|c|c|c|c|c|}
\hline & \multicolumn{6}{|c|}{ Sample period: 1994-2005 } & \multicolumn{6}{|c|}{ Sample period: 1994-2003 } \\
\hline & \multicolumn{2}{|c|}{$\begin{array}{l}\text { Demand } \\
\text { Interaction } \\
\text { Only }\end{array}$} & \multicolumn{2}{|c|}{$\begin{array}{l}\text { Exchange Rate } \\
\text { Interaction } \\
\text { Only }\end{array}$} & \multicolumn{2}{|c|}{$\begin{array}{c}\text { Both Demand } \\
\text { and Exchange } \\
\text { Rate } \\
\text { Interactions }\end{array}$} & \multicolumn{2}{|c|}{$\begin{array}{l}\text { Demand } \\
\text { Interaction } \\
\text { Only }\end{array}$} & \multicolumn{2}{|c|}{$\begin{array}{l}\text { Exchange Rate } \\
\text { Interaction } \\
\text { Only }\end{array}$} & \multicolumn{2}{|c|}{$\begin{array}{c}\text { Both Demand } \\
\text { and Exchange } \\
\text { Rate } \\
\text { Interactions }\end{array}$} \\
\hline & coef & se & coef & se & coef & se & coef & se & coef & se & coef & se \\
\hline dln_DD x SL (b6) & $0.3^{* * *}$ & 0.10 & & & 0.1 & 0.2 & $0.7^{* \star *}$ & 0.17 & & & $0.4^{* *}$ & 0.2 \\
\hline dln_REER x SL (b7) & & & $-0.6^{\star \star *}$ & 0.16 & $-0.5^{*}$ & 0.3 & & & $-0.9^{* * *}$ & 0.22 & $-0.5^{\star *}$ & 0.3 \\
\hline _cons & $0.2^{* * *}$ & 0.03 & $0.3^{* * *}$ & 0.03 & $0.2^{* * *}$ & 0.0 & $-0.1^{* *}$ & 0.04 & -0.0 & 0.04 & -0.1 & 0.0 \\
\hline Number of observations & \multicolumn{2}{|c|}{17,507} & \multicolumn{2}{|c|}{17,507} & \multicolumn{2}{|c|}{17,507} & \multicolumn{2}{|c|}{13,016} & \multicolumn{2}{|c|}{13,016} & \multicolumn{2}{|c|}{13,016} \\
\hline Number of Sectors & \multicolumn{2}{|c|}{1,532} & \multicolumn{2}{|c|}{1,532} & \multicolumn{2}{|c|}{1,532} & \multicolumn{2}{|c|}{1,525} & \multicolumn{2}{|c|}{1,525} & \multicolumn{2}{|c|}{1,525} \\
\hline R2 & \multicolumn{2}{|c|}{0.005} & \multicolumn{2}{|c|}{0.005} & \multicolumn{2}{|c|}{0.005} & \multicolumn{2}{|c|}{0.006} & \multicolumn{2}{|c|}{0.006} & \multicolumn{2}{|c|}{0.006} \\
\hline
\end{tabular}

1/ The dependent variable is the log first differenced imports. The regressors are log first differenced real effective exchange (dln_RER) log first differenced foreign and domestic demand (dln_FD and din_DD ), and interaction terms of dln_DD and dln_RER with the product sophistication level (SL). SL is represented by the dummy variables that describes the product as "low tech", "medium tech", or "high tech", as discussed in the text. The regression is performed at the five-digit level of SITC 2nd revision for all products excluding agricultural goods. Robust standard deviation is reported in the table. The model includes fixed effects for the cross sections and time effects for years. The observations include nonagricultural and non-miscellaneous products, corresponding to products with the first two-digit SITC code less than 90 and greater than 20 . 
Table 6. Export-GDP Ratio and Product Sophistication Level 1/

\begin{tabular}{|c|c|c|c|c|c|c|c|c|}
\hline & \multicolumn{2}{|c|}{$\begin{array}{c}\text { No Interaction } \\
\text { (1) } \\
\end{array}$} & \multicolumn{2}{|c|}{$\begin{array}{l}\text { Demand } \\
\text { Interaction } \\
\text { (2) }\end{array}$} & \multicolumn{2}{|c|}{$\begin{array}{l}\text { Exchange Rate } \\
\text { Interaction } \\
\text { (3) }\end{array}$} & \multicolumn{2}{|c|}{$\begin{array}{l}\text { Both Demand and } \\
\text { Exchange Rate } \\
\text { Interactions } \\
\text { (4) }\end{array}$} \\
\hline & coef & se & coef & se & coef & se & coef & se \\
\hline RER_CH & $-0.1^{\star \star *}$ & 0.0 & $-0.1^{\star \star \star}$ & 0.0 & $0.1^{\star \star \star}$ & 0.03 & $0.1^{\star \star \star}$ & 0.0 \\
\hline FD_CH & $0.7^{* \star *}$ & 0.1 & $0.5^{* *}$ & 0.1 & $0.7^{* * *}$ & 0.10 & $0.5^{\star *}$ & 0.1 \\
\hline FD_CH $\times$ SL & & & 0.1 & 0.1 & & & 0.1 & 0.1 \\
\hline RER_CH $\times$ SL & & & & & $-0.2^{* * *}$ & 0.03 & $-0.2^{\star \star \star}$ & 0.0 \\
\hline _cons & $11.2^{* \star *}$ & 0.3 & $11.2^{* * *}$ & 0.3 & $11.2^{* * *}$ & 0.32 & $11.2^{* * *}$ & 0.3 \\
\hline Number of observations & 19,5 & & 19, & & 19,5 & & 19,5 & \\
\hline Number of sectors & 1,5 & & 1,5 & & 1,5 & & 1,53 & \\
\hline R2 & 0.0 & & 0.0 & & 0.0 & & 0.00 & \\
\hline
\end{tabular}

1/ The dependent variable is the ratio of exports and GDP. The regressors are annual percentage changes of real effective exchange (RER_CH), annual growth of foreign demand (FD_CH), and interaction terms with the product sophistication level (SL). SL

is represented by the dummy variables that describes the product as "low tech", "medium tech", or "high tech", as discussed in the text. The regression is performed at the five-digit level of SITC 2 nd revision. The observations include nonagricultural and non-miscellaneous products, corresponding to products with the first two-digit SITC code less than 90 and greater than 20 . Coefficients are scaled up by 1000 , and thus represent $1 / 1000$ percentage point changes. The regression includes fixed effects for the cross section. Robust standard errors are reported. 
Table 7. Import-GDP Ratio and Product Sophistication Level 1/

\begin{tabular}{|c|c|c|c|c|c|c|c|c|}
\hline & \multicolumn{2}{|c|}{$\begin{array}{c}\text { No Interaction } \\
\text { (1) }\end{array}$} & \multicolumn{2}{|c|}{$\begin{array}{c}\text { Demand } \\
\text { Interaction } \\
(2)\end{array}$} & \multicolumn{2}{|c|}{$\begin{array}{c}\text { Exchange Rate } \\
\text { Interaction } \\
\text { (3) }\end{array}$} & \multicolumn{2}{|c|}{$\begin{array}{l}\text { Both Demand and } \\
\text { Exchange Rate } \\
\text { Interactions } \\
\text { (4) }\end{array}$} \\
\hline & coef & se & coef & se & coef & se & coef & se \\
\hline DD_CH & $0.3^{* * *}$ & 0.14 & 0.1 & 0.04 & $0.3^{* *}$ & 0.04 & 0.0 & 0.04 \\
\hline FD_CH & $0.4^{* * *}$ & 0.67 & $0.4^{* *}$ & 0.14 & $0.4^{* *}$ & 0.14 & $0.4^{* * *}$ & 0.14 \\
\hline RER_CH & $0.1^{* * *}$ & 0.24 & $0.2^{* *}$ & 0.05 & $0.3^{* * *}$ & 0.06 & $0.1^{* \star *}$ & 0.05 \\
\hline DD_CH $\times$ SL & & & $0.2^{* * *}$ & 0.05 & & & $0.2^{* * *}$ & 0.07 \\
\hline RER_CH x SL & & & & & $-0.2^{* \star *}$ & 0.05 & 0.1 & 0.08 \\
\hline _cons & $6.4^{* * *}$ & 1.52 & $6.9^{* * *}$ & 0.80 & $6.9^{* * *}$ & 0.81 & $6.9^{* * *}$ & 0.80 \\
\hline Number of observations & 22, & & 19,7 & & 19,7 & & 19,7 & \\
\hline Number of Sectors & 1,7 & & 1,5 & & 1,5 & & 1,5 & \\
\hline $\mathrm{R} 2$ & 0.0 & & 0.0 & & 0.0 & & 0.0 & \\
\hline
\end{tabular}

$1 /$ The dependent variable is the ratio of imports and GDP. The regressors are annual percentage changes of real effective exchange (RER_CH), annual growth of domestic demand(DD_CH), annual growth of foreign demand (FD_CH), and interaction terms with the product sophistication level (SL). SL is represented by the dummy variables that describes the product as "low tech", "medium tech", or "high tech". The regression is performed at the five-digit level of SITC 2nd revision. The observations include nonagricultural and non-miscellaneous products, corresponding to products with the first two digit SITC code less than 90 and greater than 20. Coefficients are scaled up by 1000 , and thus represent $1 / 1000$ percentage point changes. The regression includes fixed effects for the cross section. Robust standard errors are reported. 


\section{REFERENCES}

Bayoumi, Tamim, 1999, "Estimating Trade Equations from Aggregate Bilateral Data," IMF Working Paper No. 99/74 (Washington: International Monetary Fund).

Cerra, Valerie, and Sweta Chaman Saxena, 2003, "How Responsive is Chinese Export Supply to Market Signals," China Economic Review, Vol. 14, Issue 3, pages 350-370.

Cerra, Valeria, and Anuradha Dayal-Gulati, 1999, “China's Trade Flows: Changing Price Sensitivities and the Reform Process," IMF Working Paper No. 99/1 (Washington: International Monetary Fund).

Coudert, Virginie, and Cécile Couharde, 2005, "Real Equilibrium Exchange Rate in China," CEPII Working Paper No. 2005-01 (Paris: Centre d'Etudes Prospectives et d'Informations Internationales).

Dark, Deborah, and John Hawkins, 2005, “Why Have Imports of Australia's Goods Increased So Much?” Australia Treasury.

Dunaway, Steven, Lamin Leigh, and Xiangming Li, 2006, “How Robust are Estimates of Equilibrium Real Exchange Rates: the Case of China," IMF Working Paper No. 06/220 (Washington: International Monetary Fund).

Feenstra, Robert C., and Andrew K. Rose, 2000 "Putting Things in Order: Trade Dynamics and Product Cycles," Review of Economics and Statistics, Vol. 82, pages 369-382.

Gao, Ting, and Jiming Ha, 2006, "Reaching New Heights: Analysis of China's Foreign Trade Structure,” China International Capital Corporation Limited.

Goldstein, Morris, 2004, paper presented at the International Monetary Fund's Seminar on China’s Foreign Exchange System, “Adjusting China’s Exchange Rate Policies," Dalian, China, May.

Hiratsuka, Daisuke, 2005, "The 'Catching Up' Process of Manufacturing in East Asia," IDE Discussion Paper No. 22 (Chiba: Institute of Developing Economies).

Hummels, David, and Peter Klenow, 2005, "The Variety and Quality of a Nation's Exports," American Economic Review.

Lee, Jaewoo, and Menzie D. Chinn, 2002, "Current Account and Real Exchange Rate Dynamics in the G-7 Countries," IMF Working Paper No. 02/130 (Washington: International Monetary Fund). 
Lemoine, Francoise, and Deniz Ünal-Kesenci, 2002, "China in the International Segmentation of Production Process," CEPII Working Paper No 2002-02 (Paris: Centre d'Etudes Prospectives et d'Informations Internationales).

Rodrik, Dani, 2006, “What's So Special About China's Exports,” NBER Working Paper No. 11947 (Cambridge, Massachusetts: National Bureau of Economic Research).

Schott, Peter K., 2004, “Across-Product Versus Within-Product Specialization in International Trade," Quarterly Journal of Economics, Vol. 119, No. 2, Pages 647-678.

Schott, Peter K., 2006, “The Relative Sophistication of Chinese Exports," NBER Working Paper No. 12173 (Cambridge, Massachusetts: National Bureau of Economic Research).

Schott, Peter K., 2004, “Across-Product Versus Within-Product Specialization in International Trade," Quarterly Journal of Economics, Vol. 119, No. 2, Pages 647-678.

Shu, Chang, and Raymond Yip, 2006, "Impact of Exchange Rate Movement on the Mainland Economy,” Hong Kong Monetary Authority, China Economic Issues. 